\title{
純米醸造酒·本醸造酒の製造概況
}

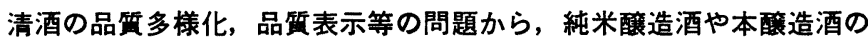 \\ 製造に関心を持っている庫は少なくない。ここに，限られた調查ではあ \\ るが，関東信越国税局管内のそれらの製造概況をまとめていただいた。 \\ 今後の製造の参考にしていただきたい。
}

関東信越国税局鑑定官室

\section{ま えがき}

昭和 51 BY の酒造も着手され始めたが，清酒業界を そりまく現況は, 需要の伸び悩み, 在庫過㮃, 原料米の コストアップ, 価格改訂, 桶取引, 低価格酒等数々の問 題をかかえた多難な年である。

したがって, 各社が適正生産量を検討して生産計画を たて, これからの清酒の品質と商品の多様化（既存のも の, 新しいタイプのすの) に対して, どのような方向へ 進めたら消費の向上をはかれるかを考えるべきだと思う 次第である。

現在, 純米醸造酒（ $\mathrm{J}$ 酒），本醸造酒（H酒）の製造， 师売を行っている酒造場は, 消費者に対して日本酒のイ メージアップをはかると伴に将来は清酒の主流にしよう と企業努力をされ, 業界全体の発展をる期待しておられ るすのと推察される。しかし, 消費者の関心が末だに低 いのは誠に残念である。

しかし, 需要が少いからと悲感することはなく, 今後 も消費者に好まれる酒質の目標と製造法を検討しつつ, 前向きた取り組む必要があろう。

本報告は, 当局で酒造場を選定して, 製造概況の実態 をまとめたものである。

\section{1. 調查対象とした酒造場}

対象酒（ $\mathrm{J}$ 酒，H酒）の課税移出量か５ $500 l$ 以上，ま たは局鑑評会〔第 21 回 (49 BY 秋), 第 22 回 (50 BY 春)】に出品し，上位成績を得た酒造場（全製造場の 17.5\%) に対して調査を依頼したもので，J酒 48 場， H 酒 52 場についての調査結果である。

ちなみに, $50 \mathrm{BY}$ の当局に括けるJ 酒, H酒の製造状 況（50 年 3 月末現在）は, 次のと扮りである。

$\begin{array}{lrr} & \mathrm{J} \text { 酒対 (前年比) } & \text { H酒 (刘前年比) } \\ \text { 場比率 } & 42.5 \%(-5.7 \%) & 50.1 \%(-1.5 \%) \\ \text { 数比率 } & 0.8 \%(-0.2 \%) & 6.7 \%(-0.6 \%)\end{array}$

\section{2. 製造, 販売の主な動機}

（1） 1 級酒は，糖類無添加酒（表示証 2，3 号）で 出荷し, 2 級酒との品質差をつける。或は, 2 級酒の需要 を伸ばすため本醸造酒を主流とする。

（2）清酒のイメージアップ（手づくり，原酒, 辛口 酒, 濃じゅん酒等で販売) をはかるため, P R 用とす る。

（3）特, 1 級酒のブレンド用, 新規取引の 開拓その 他，セット売（贈答用）等とする。

（4）小売店からの注文による。

（5）製造の動機としては，一般に表示問題の対応策 第 1 表 純米醇造酒・本䁔造の成分状況

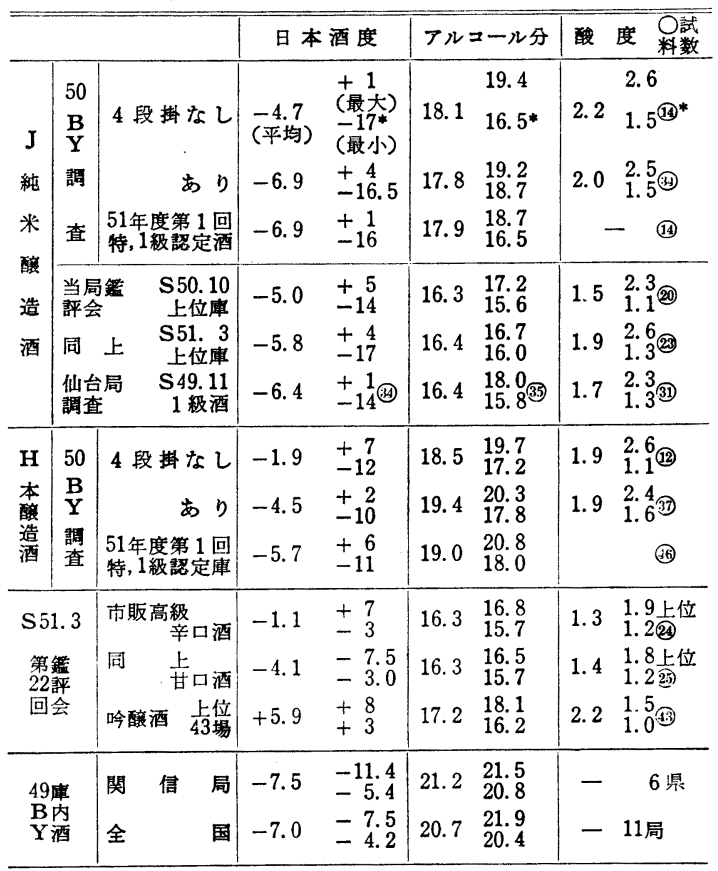

* 日本酒度, アルコール分の欄代試料数ないあのは酸度欄の数字(44)印々 同じであるため省略した。 
第 2 表 原料米の状況 (調査対象: J 48 場, H52 場)

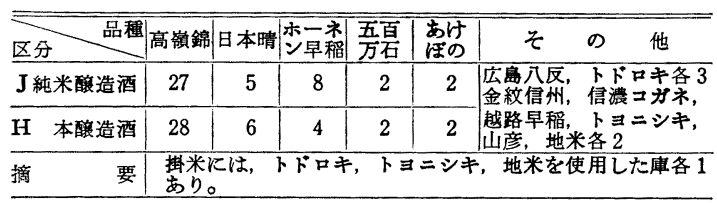

と関連があり，上記の（1）～(4) のほかに研究的段階と 考えている蔵もある。

なお，製造，販売している酒造場は，J酒 48 場のう
ち 65\%, H酒 52 場のうち約 $65 \%$ で, 2 級酒として出 荷するところは少く（J酒 $21 \% ， \mathrm{H}$ 酒 19\%)，1級酒が 多い(J酒 $59 \%, \mathrm{H}$ 酒 64\%)。

\section{3.市場の人気}

消費者の固定と今後の伸びを期待しているが，純米醸 造酒は，地方での大鼻化が難しいと見ている者が多い。 良いと答えた酒造場は， 63 場中の約 $25 \%$ で，その理 由としては，「品質において 2 級酒との差がある」「 2 級

第 3 表 平均精米歩合, 仕込配合

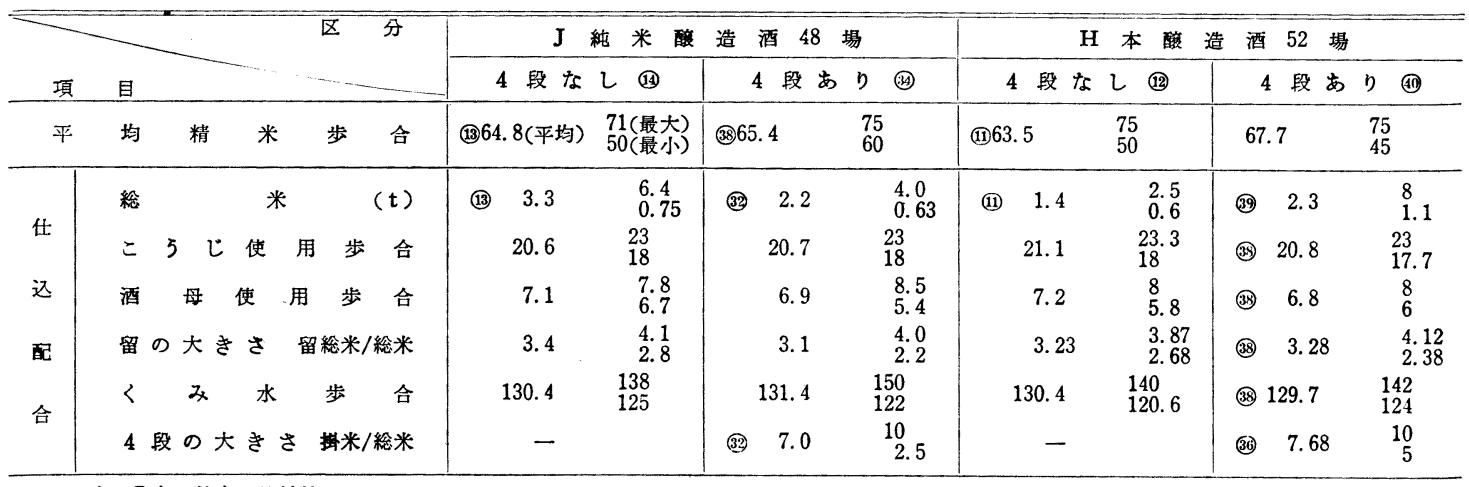

（注） ○内の数字は試料数

第 4 表 製整，酒母括よび粕歩合等の状況

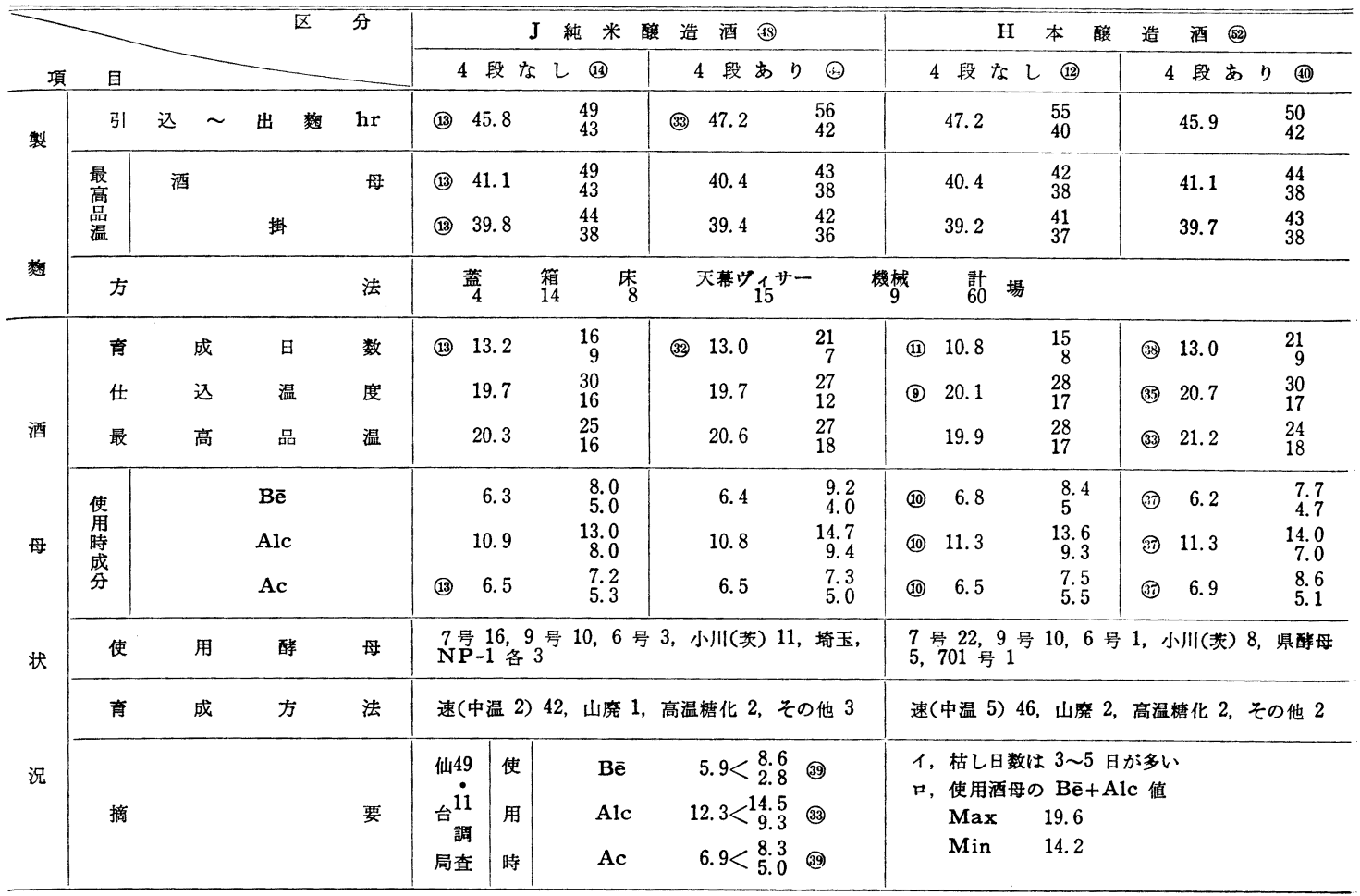


第5表モ口ミ等の状 況

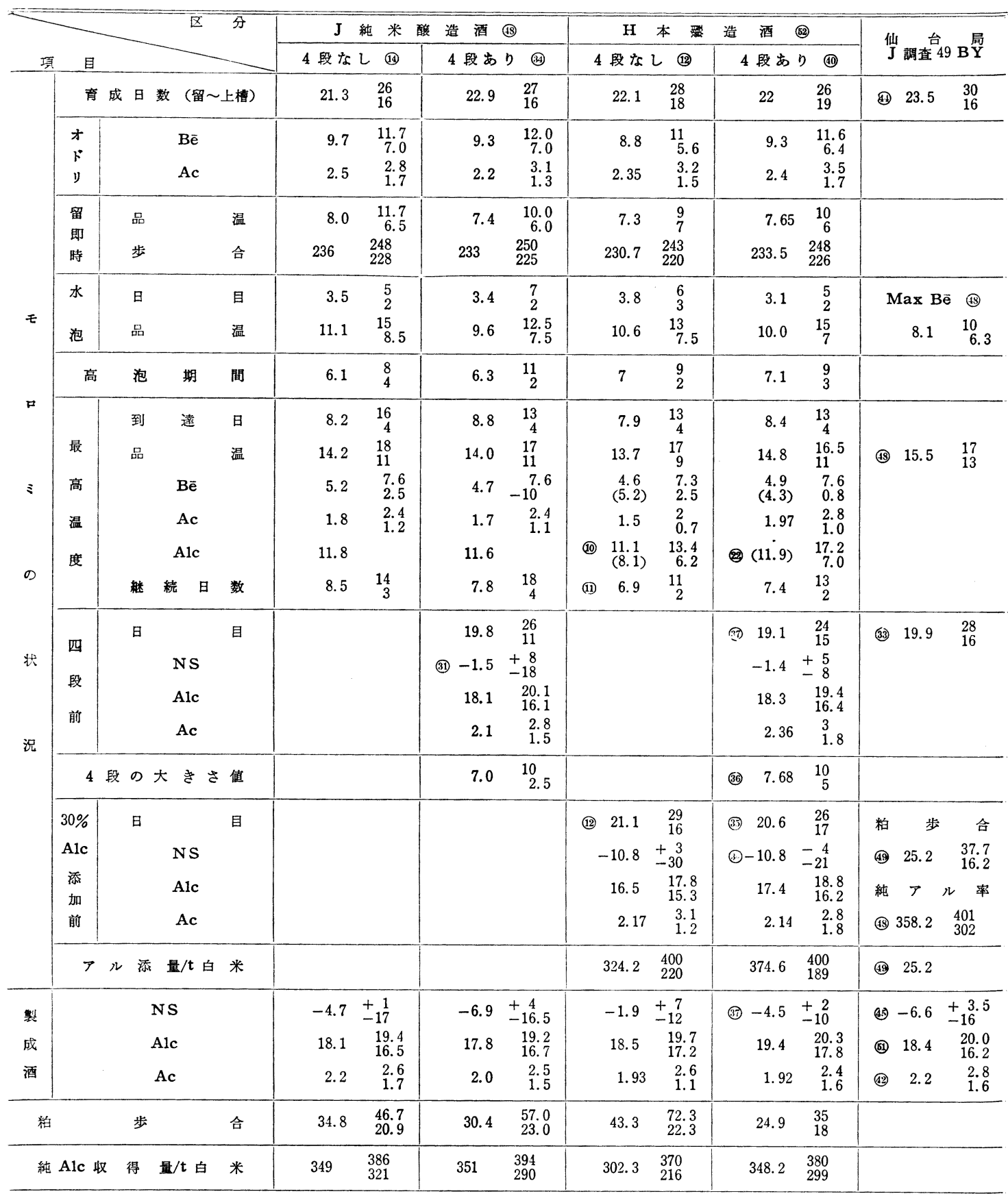

酒でも 1 級酒と変らない」「味が濃じゅん，サバケが良

いらまい」ために人気を得ている。

悪い理由としては,「価格が高い」「飲み馴れていない」 「PR不足」等をあげている。

\section{4. 市販酒（特, 1 級酒）の成分目標}

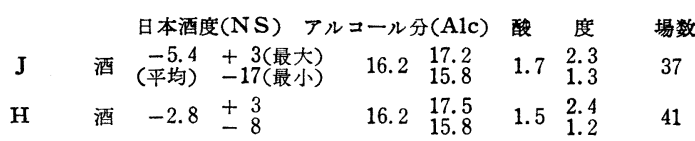




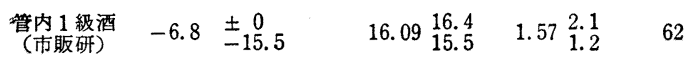

(1) J 酒

第 1 表から判断できるが，濃じゅん型の酒質である。 (2) $\mathrm{H}$ 酒

一般に, 当局鑑評会の市販高級甘口型の酒質を目標と

している。

\section{5. 製 造 状 況}

\section{（1）原料米の状況}

第 2 表のと就り，一般にコストの高い原料米を使用し ている。

（2）平均精米歩合と仕込配合（第 3 表のと扣り）

1. 平均精米歩合は, 高級酒として販売するため, 約 65\% と低くなっている。

口. 仕込配合は，全般に精白に対して標準型と見られ， 4 段の大きさも味の調整と考えられるものが多い。

（3）製稇，酒母（第 4 表のとおり）

普通酒の経過とあまり変った点は見られない。

（4）モロミ等の状況（第 5 表のと扣り）

使用酵母（協会 7,9 号, 小川等）からも第 5 表の検 討を行ったが，工場間の差が大きいため，仕込配合の 4 段なしとありの 2 区分のみで結果をまとめた。

イ. 経過

モロミ日数は, 留から上槽まで 21〜23 日が多く, 普 通酒モロミと大差がない。

品温の上昇状況は, 留から水泡時 (3.5 日頃) に 2.2 $\sim 2.9^{\circ} \mathrm{C}$, 水泡から最高到達時（6〜7 日目）は3.1〜 $4.8^{\circ} \mathrm{C}$ の上昇である。

最高温度は，H 酒の 4 段仕込が J 酒と $\mathrm{H}$ 酒 4 段なし
(中吟型の経過) よりやや高くなっている。

最高温度到達時の BMD 值は，38〜 43 の間が多く，

普通酒モロミより山が低い。

4 段による甘の戻り（NS）は，-10１2 の見込とす ると, 見掛け上の戻りが悪く， 4 段後に $-3 \sim 4$ 度の切 れがあると推定される。

口. 白米効率は, 次表のとおりである。

\begin{tabular}{|c|c|c|c|c|}
\hline $\mathrm{J}$ & 酒 & $\mathrm{H}$ & 酒 & 白米効率の算式 \\
\hline 4 段なし & 4 段あり & 4 段なし & 4 段あり & \multirow{2}{*}{ 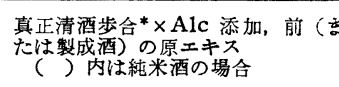 } \\
\hline 67.30 & 69.74 & 61.66 & 70.70 & \\
\hline
\end{tabular}

真正清酒歩合 $=$

$\frac{\text { 純アルコール収得量 }(l / t)}{モ \text { モロ (四段またはアル添前)のアルコール度数 } \times 10}$

$$
\text { む す び }
$$

本調査の報告において，一部酒造場では製造管理の悪 いもの及び数値の異常なものがあり, 結果の集計に取り

入れられなかった。

最近の酒造管理は, 検査, 調査の簡素化と従業員の手 不足等によってやや柾かとなっているが，酒造の基本管 理に必要な数值は常に把握し，異常の早期発見と管理の 万全を平素から心掛けることが肝要と痛感した。

清酒の需要拡大対策としては, 現在の酒, 新しい酒に ついて酒質のあり方を検討し，企業独自が小売店，消費 者を育てて行くべきだ思う。

終りに，本調査にご協力をいただいた各酒造場に対し て，厚く御礼申上げる次第です。

（文責 宮井孝一） 